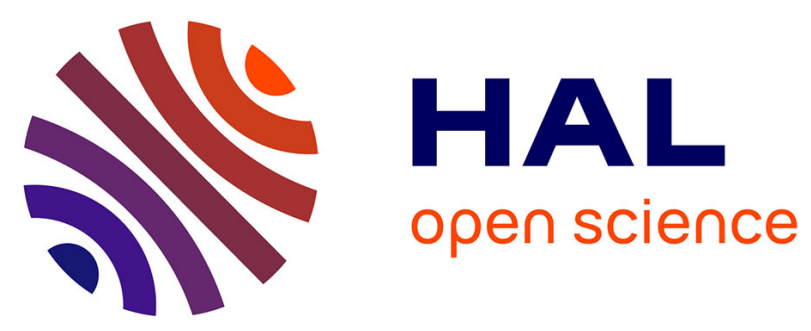

\title{
Risk of Alzheimer's disease biological misdiagnosis linked to cerebrospinal collection tubes.
}

Armand Perret-Liaudet, Mathieu Pelpel, Yannick Tholance, Benoit Dumont, Hugo Vanderstichele, Willy Zorzi, Benaissa Elmoualij, Susanna Schraen, Olivier Moreaud, Audrey Gabelle, et al.

\section{To cite this version:}

Armand Perret-Liaudet, Mathieu Pelpel, Yannick Tholance, Benoit Dumont, Hugo Vanderstichele, et al.. Risk of Alzheimer's disease biological misdiagnosis linked to cerebrospinal collection tubes.. Journal of Alzheimer's Disease, 2012, 31 (1), pp.13-20. 10.3233/JAD-2012-120361 . inserm-00726750

\section{HAL Id: inserm-00726750 https://www.hal.inserm.fr/inserm-00726750}

Submitted on 31 Aug 2012

HAL is a multi-disciplinary open access archive for the deposit and dissemination of scientific research documents, whether they are published or not. The documents may come from teaching and research institutions in France or abroad, or from public or private research centers.
L'archive ouverte pluridisciplinaire HAL, est destinée au dépôt et à la diffusion de documents scientifiques de niveau recherche, publiés ou non, émanant des établissements d'enseignement et de recherche français ou étrangers, des laboratoires publics ou privés. 


\title{
Risk of Alzheimer's Disease Biological Misdiagnosis Linked to Cerebrospinal Collection Tubes
}

\author{
Armand Perret-Liaudet ${ }^{\mathrm{a}, \mathrm{b}, *}$, Mathieu Pelpel ${ }^{\mathrm{c}}$, Yannick Tholance ${ }^{\mathrm{a}}$, Benoit Dumont ${ }^{\mathrm{a}}$, \\ Hugo Vanderstichele $^{\mathrm{d}}$, Willy Zorzi ${ }^{\mathrm{e}}$, Benaissa ElMoualij ${ }^{\mathrm{e}}$, Susanna Schraen ${ }^{\mathrm{b}, \mathrm{f}}$, Olivier Moreaud ${ }^{\mathrm{g}}$, \\ Audrey Gabelle ${ }^{\mathrm{h}}$, Eric Thouvenot ${ }^{\mathrm{h}}$, Catherine Thomas-Anterion ${ }^{\mathrm{i}}$, Jacques Touchon ${ }^{\mathrm{h}}$, \\ Pierre Krolak-Salmon $^{\mathrm{a}}$, Gabor G. Kovacs ${ }^{\mathrm{j}}$, Arnaud Coudreuse ${ }^{\mathrm{k}}$, Isabelle Quadrio ${ }^{\mathrm{a}}$ \\ and Sylvain Lehmann ${ }^{\mathrm{b}, \mathrm{h}, *}$ \\ ${ }^{\mathrm{a}}$ Neurobiologie, CMRR, Gériatrie, Hospices Civils de Lyon, Université Lyon 1 - CNRS UMR5292 - INSERM \\ U1028, Lyon, France \\ ${ }^{\mathrm{b}}$ Société Française de Biologie Clinique (SFBC), France \\ ${ }^{\mathrm{c}}$ Technical and QA Department, Innogenetics, Les Ulis, France \\ ${ }^{\mathrm{d}}$ ADx NeuroSciences, Technologiepark, Gent, Belgium \\ ${ }^{\mathrm{e}}$ Human Histology-CRPP, University of Liège, Liège, Belgium \\ ${ }^{\mathrm{f}} \mathrm{CHU}$ de Lille, France; INSERM, U837, France \\ ${ }^{\mathrm{g}} \mathrm{CMRR}$, CHU de Grenoble, France \\ ${ }^{\mathrm{h}}$ CHU de Montpellier, IRB, INSERM-UM1 1040, INSERM U1061, France \\ ${ }^{\mathrm{i}} \mathrm{CMRR}$, Neurologie, $\mathrm{CHU}$ de Saint-Etienne, France \\ $\mathrm{j}$ Institute of Neurology, Medical University of Vienna, Vienna, Austria \\ ${ }^{\mathrm{k}}$ Centre de Transfert de Technologie du Mans, Le Mans, France
}

Handling Associate Editor: Julien Dumurgier

\begin{abstract}
Tau proteins and amyloid- $\beta$ (A $\beta$ ) peptides are the current recognized cerebrospinal fluid (CSF) biomarkers used as an aid in the diagnosis of Alzheimer's disease (AD). However, there is no consensus on their clinical use due to non-qualified cut-off values, probably related to the observed high pre-analytical and analytical variability. Standardized pre-analytical protocols have therefore been proposed. Importantly, these recommend the use of polypropylene collection/sampling tubes while, to date, no broad comparison of these types of tubes has been conducted. In this study, we first compared, as part of a real clinical workflow, the impact of four different collection tubes on the CSF concentration of $A \beta$ peptides $\left(A \beta_{42}, A \beta_{40}\right)$ and total (hTau) and phosphorylated (P-Tau181P) tau proteins measured using routine ELISA kits. We then extended this study to 11 polypropylene tubes used by different clinical laboratories, and investigated their plastic polymer composition using differential scanning calorimetry and Fourier Transformed Infrared spectroscopy. Significant concentration variations linked solely to the use of different types of tubes were observed. This was particularly marked for $\mathrm{A} \beta$ peptides, with $>50 \%$ disparity occurring in less than five minutes. Polymer
\end{abstract}

\footnotetext{
${ }^{*}$ Correspondence to: Sylvain Lehmann, Institut de Recherche en Biothérapie, 80 Avenue Augustin Fliche, 34295 Montpellier, France. E-mail: s-lehmann@chu-montpellier.fr and Armand Perret-Liaudet, Service de Neurobiologie, Hospices Civils de Lyon, 69677 Bron, France; E-mail: E-mail: armand.perret-liaudet@chu-lyon.fr.
} 
composition analysis revealed that most polypropylene tubes were in fact copolymers with at least polyethylene. There was no clear correlation between tube composition and pre-analytical behavior. Our results show that the use of polypropylene tubes does not guarantee satisfactory pre-analytical behavior. They also point to collection/sampling tubes being a major pre-analytical source of variability that could impact the significance of AD biological diagnosis.

Keywords: Alzheimer's disease, cerebrospinal fluid, collection tubes, standardization

\section{INTRODUCTION}

Total tau protein (hTau), its phosphorylated isoform at position 181 (p-Tau181P), and amyloid- $\beta(A \beta)$ peptides $\left(A \beta_{42}\right.$ and $\left.A \beta_{40}\right)$ are the current accepted cerebrospinal fluid (CSF) biomarkers used as an aid in the diagnosis of Alzheimer's disease (AD) [1-5]. They help characterize atypical phenotypes, stratify patients in clinical trials, and predict AD conversion in prodromal forms $[4,6,7]$. Due notably to important between-center variability $[2,8,9]$, there is no consensus on their use and their cut-off values to define a CSF $\mathrm{AD}$ signature. Investigation of pre-analytical events affecting the levels of these biomarkers identified delay of processing, storage in different types of tubes, volume per tube, dilution with detergent-containing buffer, plasma contamination, and heat treatment as significant factors [10-13].

To minimize pre-analytical and analytical errors, standardized operating procedures have been proposed $[8,10,11]$. Importantly, they all recommend the use of polypropylene tubes instead of polystyrene or glass. However, only a descriptive study on influence of collection tubes onto the CSF $A \beta_{42}$ was conducted [14]. In a recent letter we reported major differences between collection tubes [15]. Here, we significantly extended this initial study. We completed the comparison in a real clinical workflow using four different collection tubes. We also extended our study of 11 polypropylene tubes, looking at their biomarker performance in relation with their plastic polymer composition.

Our results show that the use of polypropylene tubes does not guarantee satisfactory pre-analytical behavior. They also point to collection/sampling tubes being a major pre-analytical source of variability that could impact the significance of AD biological diagnosis.

\section{MATERIALS AND METHODS}

\section{Study participants}

Samples originated from biobanks generated in two French Clinical and Research Memory Centres
(CMRRs) specialized in the care of cognitive disorders based in Lyon and Montpellier. Recruited patients gave their written informed consent to participate in the biobanks (registered \# DC-2008-417). As the focus of this study was analytical, samples were selected to cover the different neurochemical situations corresponding to different diagnoses, and with variable concentrations of biomarkers (Fig. 1).

\section{CSF sampling and analysis}

In a first series of experiments (Figs. 1 and 2), CSF from 12 patients was collected directly in four different types of tubes ( $2 \mathrm{~mL}$ per tube): ST-PP (Sarstedt, $10 \mathrm{~mL}$, polypropylene, ref. 62.610.201); HE-PS (Fisher Scientific hemolysis tube, $5 \mathrm{~mL}$, polystyrene, ref. W1773X); BD-PE (Becton Dickinson, $14 \mathrm{~mL}$, polystyrene, ref. 352095), and BD-PP (Becton Dickinson, $15 \mathrm{~mL}$, polypropylene, ref. 352096). Collection tubes were transported on ice to the laboratory and processed immediately by centrifugation ( $10 \mathrm{~min}, 1000 \mathrm{~g}$ ).

Samples were divided into $0.5 \mathrm{~mL}$ aliquots in polypropylene Eppendorf tubes (Protein LoBind, ref: 0030108.116.), stored at $-80^{\circ} \mathrm{C}$ (less than 6 month), and thawed immediately before quantification. In some cases (Fig. 2A, B), freshly thawed samples were distributed in ST-PP tubes for the indicated period of time at $2-8^{\circ} \mathrm{C}$, or were supplemented with human albumin for the indicated final concentrations and kept for $1 \mathrm{~h}$ in ST-PP tubes before measurement.

In a second series of experiments (Fig. 3, Tables 2), six non-hemorrhagic CSF samples were collected directly in the tube $\mathbf{J}$ (Table 1), transported in less than $15 \mathrm{~min}$ to the laboratory and processed immediately by centrifugation $(10 \mathrm{~min}, 1000 \mathrm{~g}$ ). After homogenization, $300 \mu$ l of the supernatant was distributed in every one of the 11 tubes (see Table 1 for description of tubes) and left for $15 \mathrm{~min}$ (T1) or $24 \mathrm{~h} \mathrm{(T2)} \mathrm{at} 2-8^{\circ} \mathrm{C}$. They were then stored at $-80^{\circ} \mathrm{C}$ and thawed before immediate quantification.

CSF $A \beta_{42}, A \beta_{40}$, hTau, and p-Tau181P concentrations were measured using standardized commercially available INNOTEST ${ }^{\circledR} /$ IBL sandwich ELISA tests 

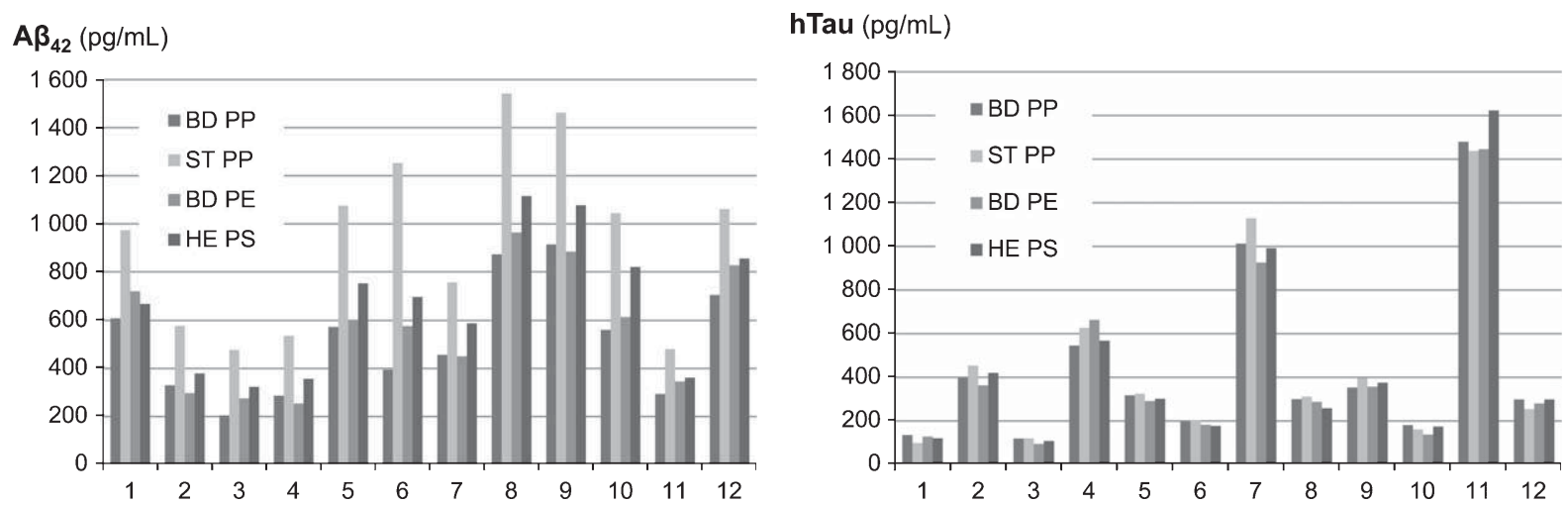

\section{p-Tau181P $(\mathrm{pl} / \mathrm{mL})$}
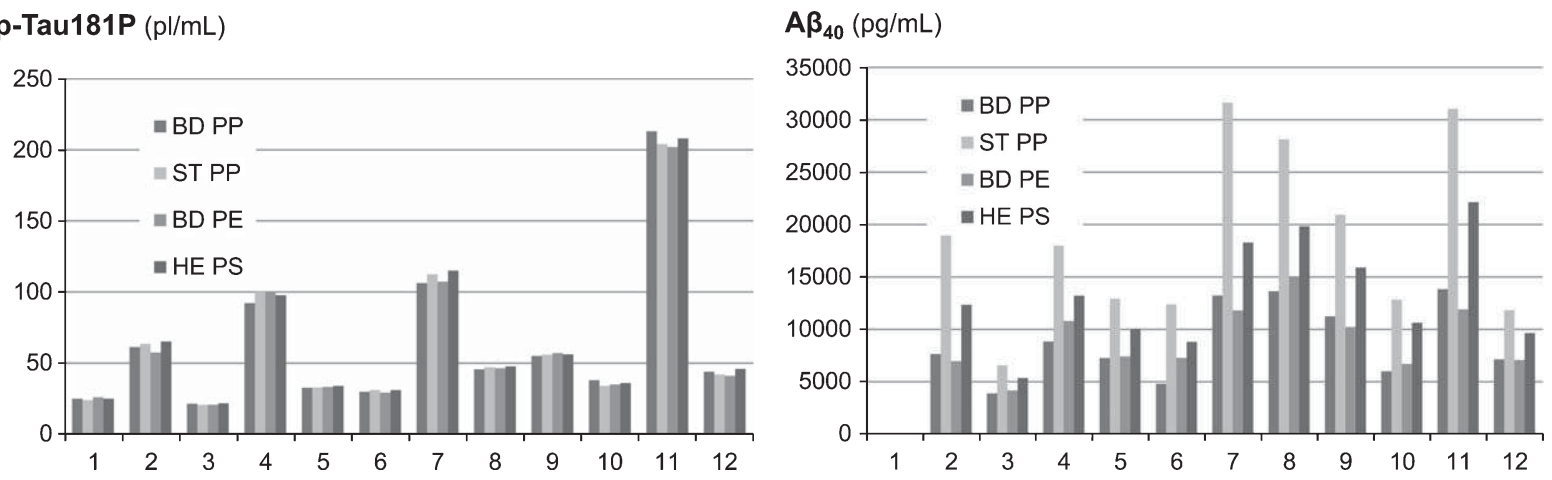

Fig. 1. Individual AD biomarker results from four different tube types. CSF from twelve patients was collected in four different types of tubes: BD-PP, ST-PP, BD-PE, and HE-PS. After CSF processing, CSF A $\beta_{42}$, hTau, p-Tau181P, and A $\beta_{40}$ were measured using commercially available ELISA tests. For $A \beta_{40}$ one sample is missing. Note: results are expressed as the mean of two values. Variability between most sample duplicates was in the range of the intra-assay CVs (from 2 to $8 \%$ ). Some duplicates corresponding to low values were between 8 and $15 \%$. Statistical analysis showed that the four tubes all differs ( $p$-values below 0.05) for CSF A $\beta_{42}$ and A $\beta_{40}$. For hTau, only BD-PE differs from BD-PP and ST-PP while for p-Tau181P, HE-PS differs from the tree other tubes. A $\beta$, amyloid- $\beta$ protein; hTau, total Tau protein; $p$-Tau181P, Tau protein phosphorylated at position 181 .

according to the supplier's instructions (Innogenetics, Ghent, Belgium). To reduce variability, the analysis of each series was performed within same experiment using the same batch of kits. Intra-assays CVs were $<5 \%$ for $\mathrm{A} \beta \mathrm{s}$ and $\mathrm{p}$-Tau181P, and $<8 \%$ for hTau.

\section{Statistical analyses}

Statistical analyses were performed and graphs prepared using XLSTAT and MedCalc (7.3) software. Graphical results were presented as medians and interquartile ranges. The impact of tube type was assessed using a non-parametric test on the percentage of concentration deviation for each tube to the average concentration value for each CSF sample. A KruskalWallis test was used for comparison of $\mathrm{k}$ samples with a significance level set at 5\%. The tubes were compared two by two with a bilateral test using the Conover-Iman procedure.

\section{Tube analysis}

Physical analysis of the tubes was performed using two methods [16]. Differential scanning calorimetry, which is a measurement of a phase change of the material, those phase changes being characteristic for a material; melting points were measured and compared to polyolefin references. Fourier Transformed Infrared spectroscopy measures the absorption by a sample of polychromatic radiation in the infrared domain, this absorption being characteristic of the chemical groups present in the sample. Thus, the spectrum obtained is specific to the sample's material or to the material family. The spectra were acquired in reflexion mode giving a surface analysis with a probe depth of 1 to $5 \mu \mathrm{m}$.

\section{RESULTS}

To investigate pre-analytical variations linked solely to sampling tubes, CSF samples from 12 patients 


\section{A}

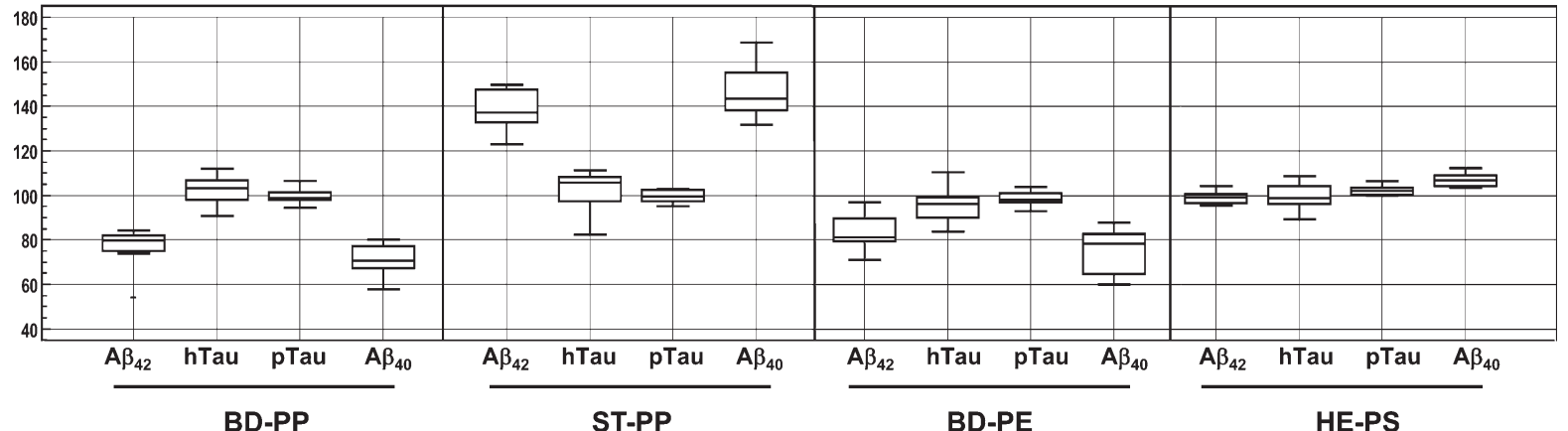

B

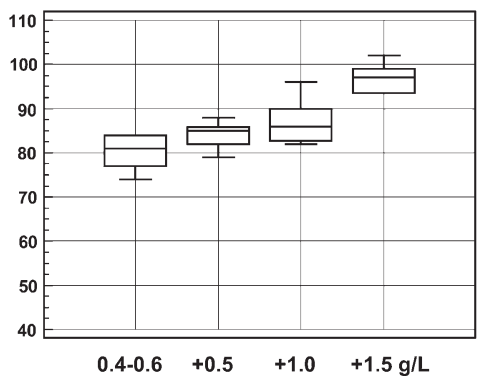

$\mathrm{C}$

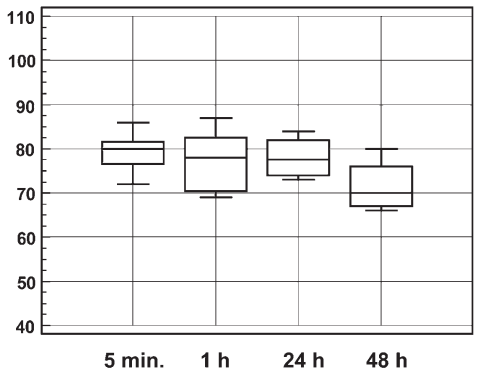

Fig. 2. Median AD biomarker results using four different tube types, along with the effect of time delay and protein concentrations on the results (in \%). A) CSF from twelve patients was collected in four different types of tubes: BD-PP, ST-PP, BD-PE. and HE-PS. CSF A $\beta_{42}$, hTau, p-Tau 181P, and $A \beta_{40}$, were measured using commercially available ELISA tests (Fig. 1). For each individual sample, measured concentrations were converted as a percentage of the mean of the values obtained in the four tubes. Results are presented as medians and interquartile ranges. B) Four freshly thawed CSF samples with protein content ranging from 0.4 to $0.6 \mathrm{~g} / \mathrm{L}$ were supplemented with human albumin to raise their protein concentration by $0,0.5,1.0$, and $1.5 \mathrm{~g} / \mathrm{L}$. These samples were then distributed in ST-PP tubes and left for $1 \mathrm{~h}$ at $2-8^{\circ} \mathrm{C}$ before $\mathrm{A} \beta_{42}$ measurement. The graph reports the percentage concentration remaining of the initial $\mathrm{A} \beta_{42}$ values. C) Four freshly thawed CSF samples were distributed in ST-PP tubes for the indicated period of time at $2-8^{\circ} \mathrm{C}$. The graph reports the percentage concentration remaining of the initial $\mathrm{A} \beta_{42}$ values.

enrolled in an ethically approved study were directly (from the lumbar puncture needle) collected in four different types of tubes: two polypropylene tubes, one polystyrene tube, and one polyethylene tube. hTau, p-Tau181P, $A \beta_{42}$, and $A \beta_{40}$ concentrations were then measured in parallel (Fig. 1).

When the results were expressed as a percentage of the median value obtain in the four tubes (Fig. 2), biomarkers concentration showed major variations that were significantly different in many cases in particular for $A \beta$ peptides (Fig. 1). Median values for $A \beta_{42}$ peptides were for example of $80 \%, 137 \%, 81 \%$, and $99 \%$ in BD-PP, ST-PP, BD-PE, and HE-PS tubes, respectively. In individual patient samples (Fig. 1), this effect was present over the whole range of $A \beta$ values. These data confirmed and extended previous observation by Pica-Mendez et al. [14].

In summary, much higher $A \beta_{42}$ and $A \beta_{40}$ concentrations were observed in ST-PP tubes compared to the other tubes. Statistical differences between non polypropylene tubes were also observed for hTau (HEPS) and p-Tau181P (BD-PE) (Fig. 1). This clearly illustrated that each tube has its own pre-analytical property.

In contrast with common knowledge and recommendations, it was clear that using polypropylene tubes did not always result in optimal pre-analytical behavior. Importantly, the type of tube used for the same patient could dramatically change the interpretation of the biomarker results, leading therefore to possible $\mathrm{AD}$ misdiagnosis (see individual concentration values on Fig. 1). hTau and p-Tau181P were, however, less affected by the type of tubes, confirming the importance of evaluating $A \beta$ peptides concentration in combination with these biomarkers.

To further explain the role of collection tubes on resulting biomarker values, we selected 11 different commercially available polypropylene collection tubes (Table 1), some of them being used by different clinical teams in the AD field. We performed an evaluation 

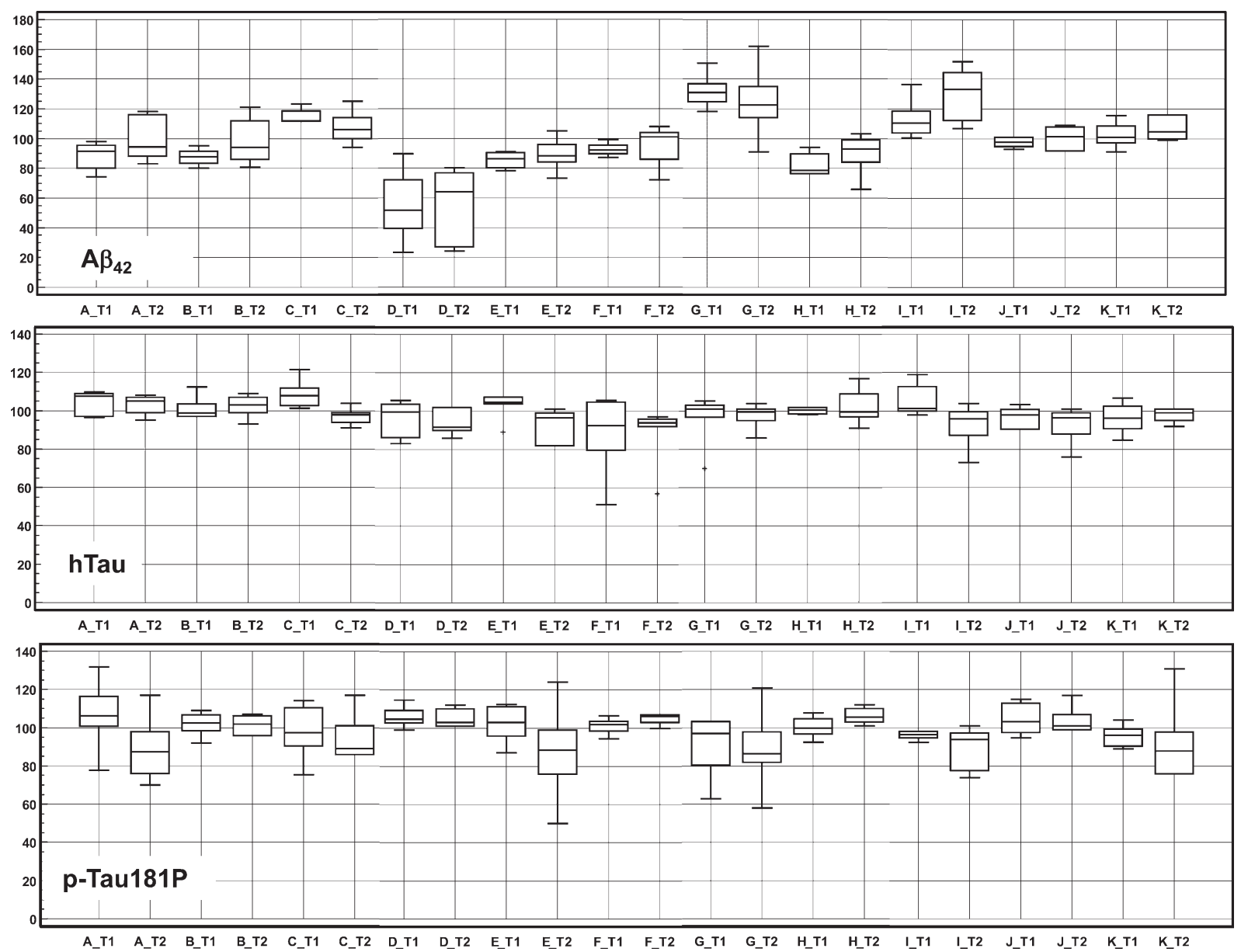

Fig. 3. Effect of time delay on median AD biomarker results from 11 different tube types (in \%). After collection in one tube (J, Table 1) and centrifugation, six CSF supernatants samples were homogenized and distributed into 11 different tubes (A to K, see Table 1) and left at 2-8 ${ }^{\circ} \mathrm{C}$ for $15 \mathrm{~min}(\mathrm{~T} 1)$ or for $24 \mathrm{~h}(\mathrm{~T} 2)$ before $\mathrm{A} \beta_{42}$, hTau, and p-Tau181P were measured using commercially available ELISA tests. For each individual sample, the measured concentrations were converted as a percentage of the mean of the values obtained in the 11 tubes. Results are presented as medians and interquartile ranges. Statistical analysis showed no differences ( $p$-values below 0.05$)$ between T1 and T2 in the 11 tubes. A $\beta$, amyloid- $\beta$ protein; hTau, total Tau protein; $\mathrm{p}$-Tau181P, Tau protein phosphorylated at position 181.

Table 1

Impact of polypropylene collection tubes on AD biomarkers and surface polymer composition analysis using differential scanning calorimetry and Fourier Transformed Infrared spectroscopy

\begin{tabular}{|c|c|c|c|c|c|c|}
\hline Tube & Provider & Catalog numbers & Vol (mL) & Peak maximum $\left({ }^{\circ} \mathrm{C}\right)$ & Peaks super-position & Identification \\
\hline A & Greiner & 188280 & 15 & 151.61 & 2 & PP-PE copolymer \\
\hline B & Greiner & 188281 & 15 & 150.75 & 2 & PP-PE copolymer \\
\hline $\mathrm{C}$ & Deltalab & 401402 & 12 & 149.99 & 2 & PP-PE copolymer \\
\hline $\mathrm{D}$ & Evergreen & 222-3529-G8D & 30 & 15.32 & 2 & PP-PE copolymer \\
\hline $\mathrm{E}$ & CML & TC15PP & 15 & 150.39 & 2 & PP-PE copolymer \\
\hline $\mathrm{F}$ & Sarstedt & 629.924 .284 & 10 & 149.83 & 3 & $\mathrm{PP}-\mathrm{PE}+?$ \\
\hline G & Sarstedt & 62.610 .201 & 10 & 150.16 & 3 & $\mathrm{PP}-\mathrm{PE}+?$ \\
\hline $\mathrm{H}$ & Falcon & BD 352006 & 14 & 150.54 & 2 & PP-PE copolymer \\
\hline I & Nalgene & 342805 & 2 & 151.63 & 3 & $\mathrm{PP}-\mathrm{PE}+?$ \\
\hline $\mathrm{J}$ & Falcon & BD 352096 & 15 & 150.75 & 2 & PP-PE copolymer \\
\hline $\mathrm{K}$ & Gosselin & TK75-085 & 5 & 168.25 & 1 & $\mathrm{PP}$ \\
\hline
\end{tabular}

Six CSF supernatants of freshly collected samples were distributed in to the 11 tubes for 15 min and A $\beta_{42}$, hTau, and p-Tau181P were measured using commercially available ELISA tests. For each individual sample, the measured concentrations were converted as a percentage of the mean of the values obtained in the 11 tubes. The median of the different percentage are reported in the table. PP, polypropylene; PE, polyethylene. 
Table 2

Statistical differences between values in the 11 tubes (A to K, see Table 1 and Fig. 3)

\begin{tabular}{|c|c|c|c|c|c|c|c|c|c|c|c|}
\hline $\mathrm{A} \beta_{1-42}$ & A & B & $\mathrm{C}$ & D & $\mathrm{E}$ & $\mathrm{F}$ & G & $\mathrm{H}$ & I & $\mathrm{J}$ & $\mathrm{K}$ \\
\hline $\mathrm{A}$ & 1 & 0.429 & $<0.0001$ & $<0.001$ & 0.159 & 0.448 & $<0.0001$ & 0.029 & $<0.0001$ & 0.003 & 0.001 \\
\hline B & & 1 & $<0.0001$ & 0.003 & 0.531 & 0.124 & $<0.0001$ & 0.154 & $<0.0001$ & $<0.001$ & $<0.0001$ \\
\hline $\mathrm{C}$ & & & 1 & $<0.0001$ & $<0.0001$ & $<0.0001$ & 0.064 & $<0.0001$ & 0.895 & 0.022 & 0.051 \\
\hline D & & & & 1 & 0.018 & $<0.0001$ & $<0.0001$ & 0.109 & $<0.0001$ & $<0.0001$ & $<0.0001$ \\
\hline $\mathrm{E}$ & & & & & 1 & 0.033 & $<0.0001$ & 0.419 & $<0.0001$ & $<0.0001$ & $<0.0001$ \\
\hline $\mathrm{F}$ & & & & & & 1 & $<0.0001$ & 0.004 & $<0.0001$ & 0.026 & 0.010 \\
\hline G & & & & & & & 1 & $<0.0001$ & 0.084 & $<0.0001$ & $<0.001$ \\
\hline $\mathrm{H}$ & & & & & & & & 1 & $<0.0001$ & $<0.0001$ & $<0.0001$ \\
\hline I & & & & & & & & & 1 & 0.016 & 0.038 \\
\hline $\mathrm{J}$ & & & & & & & & & & 1 & 0.716 \\
\hline K & & & & & & & & & & & 1 \\
\hline \multicolumn{12}{|l|}{ hTau } \\
\hline A & 1 & 0.197 & 0.414 & 0.106 & 0.962 & 0.035 & 0.166 & 0.314 & 0.797 & 0.035 & 0.087 \\
\hline B & & 1 & 0.038 & 0.736 & 0.181 & 0.396 & 0.923 & 0.773 & 0.299 & 0.396 & 0.665 \\
\hline $\mathrm{C}$ & & & 1 & 0.017 & 0.442 & 0.004 & 0.030 & 0.071 & 0.285 & 0.004 & 0.013 \\
\hline $\mathrm{D}$ & & & & 1 & 0.096 & 0.608 & 0.810 & 0.532 & 0.171 & 0.608 & 0.923 \\
\hline $\mathrm{E}$ & & & & & 1 & 0.031 & 0.152 & 0.292 & 0.760 & 0.031 & 0.079 \\
\hline $\mathrm{F}$ & & & & & & 1 & 0.452 & 0.257 & 0.062 & 1.000 & 0.677 \\
\hline G & & & & & & & 1 & 0.700 & 0.257 & 0.452 & 0.736 \\
\hline $\mathrm{H}$ & & & & & & & & 1 & 0.452 & 0.257 & 0.471 \\
\hline I & & & & & & & & & 1 & 0.062 & 0.144 \\
\hline $\mathrm{J}$ & & & & & & & & & & 1 & 0.677 \\
\hline K & & & & & & & & & & & 1 \\
\hline \multicolumn{12}{|l|}{ pTau } \\
\hline A & 1 & 0.510 & 0.211 & 0.748 & 0.600 & 0.355 & 0.043 & 0.267 & 0.070 & 0.741 & 0.046 \\
\hline B & & 1 & 0.551 & 0.344 & 0.916 & 0.789 & 0.165 & 0.648 & 0.241 & 0.741 & 0.175 \\
\hline $\mathrm{C}$ & & & 1 & 0.132 & 0.501 & 0.741 & 0.424 & 0.887 & 0.561 & 0.355 & 0.442 \\
\hline $\mathrm{D}$ & & & & 1 & 0.419 & 0.231 & 0.026 & 0.169 & 0.042 & 0.525 & 0.027 \\
\hline E & & & & & 1 & 0.719 & 0.154 & 0.590 & 0.222 & 0.834 & 0.162 \\
\hline $\mathrm{F}$ & & & & & & 1 & 0.260 & 0.850 & 0.363 & 0.551 & 0.273 \\
\hline G & & & & & & & 1 & 0.347 & 0.826 & 0.088 & 0.975 \\
\hline $\mathrm{H}$ & & & & & & & & 1 & 0.470 & 0.433 & 0.363 \\
\hline I & & & & & & & & & 1 & 0.135 & 0.850 \\
\hline $\mathrm{J}$ & & & & & & & & & & 1 & 0.094 \\
\hline K & & & & & & & & & & & 1 \\
\hline
\end{tabular}

$p$-values are reported, values below 0.05 are in bold italics.

of their impact on the three classical AD biomarkers, as well as carrying out a surface polymer composition analysis using differential scanning calorimetry and Fourier Transformed Infrared spectroscopy. This revealed surprising results with only one tube consisting of pure polypropylene, the others being copolymers with at least polyethylene; even-though they were all labeled as polypropylene (Table 1). Regulations in fact allow companies to label tubes as being purely polypropylene even in the presence of other polymers or surface treatment. Incidentally, the exact polymer composition of the different tubes was not disclosed by most of the commercial providers.

Using a series of fresh (unfrozen) CSF samples from 6 patients, we then distributed them between the 11 tubes and waited $15 \mathrm{~min}$ (T1) or $24 \mathrm{~h}$ (T2) before processing the samples using the same analytical conditions (Table 2). This revealed significant differences between tubes (Table 2 ) with maximum median variations of $-48 \% /+31 \%,-8 \% /+8 \%$, and $-4 \% /+6 \%$, for $\mathrm{A} \beta_{42}$, hTau, and p-Tau181P, respectively.

When hTau and p-Tau181P were in the range of acceptable and observed analytical variations for these biomarkers, differences in $A \beta_{42}$ concentrations clearly exceeded them. The effect was present after $15 \mathrm{~min}$ (T1), and an additional $24 \mathrm{~h}$ (T2) incubation time at $2-8^{\circ} \mathrm{C}$ did not significantly change these values (Fig. 3).

Adsorption of the biomarkers on the tube surface was the most likely explanation for this "tube effect" [17]. This explanation is consistent with previous unpublished observations suggesting that CSF biomarker levels in samples with high protein content $(>1.5 \mathrm{~g} / \mathrm{L})$ were not changed by the type of collection tube, especially in comparison with samples with low protein content. To confirm this observation, we 
confirmed that artificially raising the protein content of CSF samples resulted in a disappearance of the tube effect (Fig. 1B). This was also coherent with the time course of this effect that was tested in the tube with the apparent higher $A \beta$ values (ST-PP, Fig. 1C). This experiment revealed a $20 \%$ decrease in $A \beta$ peptides concentration as early as 5 min after contact with the tube. This means that when CSF is in contact with a tube, $A \beta$ peptide values drop almost immediately, and this effect is iterative (values drops again when put in a new tube; not shown). Importantly, after these first $5 \mathrm{~min}$, the impact of additional time ( 24 and $48 \mathrm{~h}$ ), mimicking a pre-analytical delay, was minimal and not significant up to $48 \mathrm{~h}$ (Figs. 1C and 3).

Surprisingly, the pure polypropylene tube (tube K) did not give the best results and differences between tubes suggested that additional surface treatment could also change the adsorption properties of the tubes.

\section{DISCUSSION}

The high pre-analytical sensibility of $A \beta$ to different polymer/plastic surfaces is an important observation to take into account. Transfer of CSF in to different tubes during processing or storage can result in a $20 \%$ to $60 \%$ decrease in measured concentrations. In addition, analytical protocols often contain intermediate steps involving transfer of CSF samples into new tubes or plates, resulting in possible errors. This is true, not only for $A \beta_{42}$, but also for other $A \beta$ peptides $\left(A \beta_{40}, A \beta_{38}\right.$, not shown), which are of interest for the diagnosis of other neurological diseases [18]. Selection of collection tubes that would preserve the best $\mathrm{A} \beta$ peptides content would therefore make sense.

Adsorption of these analytes to the tube walls is the most likely explanation for these phenomena. An interesting trend was observed since some tubes that performed better for $\mathrm{p}$-Tau181P were the worst for $A \beta_{42}$ (tubes $D$ and $A$ ). This suggests that the hydrophilic/hydrophobic balance of the analytes plays an important role in this phenomenon: the more hydrophobic $A \beta_{42}$ peptide is greatly adsorbed by some of the tubes. On the other hand, probably due to its high content in anionic phosphate groups, $\mathrm{p}$-Tau181P which is more hydrophilic, is less adsorbed by the tubes which adsorbed the $A \beta_{42}$ protein. Hydrophilicity due to the polymer surface composition is an important point in understanding the adsorption of proteins but other parameters may affect this absorption such as the polymer surface charge in regard with the isoelectric point of the protein, or the surface roughness
$[16,19,20]$. It has been shown that changing both the hydrophilicity and the charge of the surface may lead to great improvement in the protein recovery [21] underlying the fact that the tube composition and its possible surface treatment is a key parameter in protein adsorption.

In summary, our data indicated that the preanalytical impact of sampling/processing tubes has to be particularly well optimized and harmonized for multi-site studies and for the definition of relevant and worldwide AD biomarker cut-off values. One way to go is probably to define a consensus protocol that specifically links cut-off values to given sampling tubes and handling/analytical protocols.

\section{ACKNOWLEDGMENTS}

This work was in part realized in the framework of a working group of the "Société Française de Biologie Clinique" (SFBC). It was supported in part for the Montpellier team by "France Alzheimer" and through the National French Alzheimer effort ("Plan Alzheimer") and for the teams of Lyon, Le Mans, Liège and Vienna by the EU FP6 Project Neuroscreen LSHB-CZ-2006-037719 and by the Région Wallonne, W2002134 and 14531-iPCRq contracts for Liège.

Mathieu Pelpel is an employee of the diagnostic company Innogenetics ${ }^{\circledR}$ which commercializes diagnostic ELISA tests for Alzheimer Disease. In this study, Mathieu Pelpel was not directly involved in the setting or the design of the experiments.

Authors' disclosures available online (http://www.jalz.com/disclosures/view.php?id=1230).

\section{REFERENCES}

[1] Shaw LM, Vanderstichele H, Knapik-Czajka M, Clark CM, Aisen PS, Petersen RC, Blennow K, Soares H, Simon A, Lewczuk P, Dean R, Siemers E, Potter W, Lee VM, Trojanowski JQ (2009) Cerebrospinal fluid biomarker signature in Alzheimer's disease neuroimaging initiative subjects. Ann Neurol 65, 403-413.

[2] Mattsson N, Zetterberg H, Hansson O, Andreasen N, Parnetti L, Jonsson M, Herukka SK, van der Flier WM, Blankenstein MA, Ewers M, Rich K, Kaiser E, Verbeek M, Tsolaki M, Mulugeta E, Rosén E, Aarsland D, Visser PJ, Schröder J, Marcusson J, de Leon M, Hampel H, Scheltens P, Pirttilä T, Wallin A, Jönhagen ME, Minthon L, Winblad B, Blennow $\mathrm{K}$ (2009) CSF biomarkers and incipient Alzheimer disease in patients with mild cognitive impairment. JAMA 302, 385-393.

[3] Wiltfang J, Esselmann H, Bibl M, Hüll M, Hampel H, Kessler H, Frölich L, Schröder J, Peters O, Jessen F, Luckhaus C, Perneczky R, Jahn H, Fiszer M, Maler JM, Zimmermann R, Bruckmoser R, Kornhuber J, Lewczuk P (2007) Amyloid beta 
peptide ratio $42 / 40$ but not A beta 42 correlates with phosphotau in patients with low- and high-CSF A beta 40 load. J Neurochem 101, 1053-1059.

[4] Dubois B, Feldman HH, Jacova C, Cummings JL, Dekosky ST, Barberger-Gateau P, Delacourte A, Frisoni G, Fox NC, Galasko D, Gauthier S, Hampel H, Jicha GA, Meguro K, O'Brien J, Pasquier F, Robert P, Rossor M, Salloway S, Sarazin M, de Souza LC, Stern Y, Visser PJ, Scheltens P (2010) Revising the definition of Alzheimer's disease: A new lexicon. Lancet Neurol 9, 1118-1127.

[5] Andreasen N, Hesse C, Davidsson P, Minthon L, Wallin A, Winblad B, Vanderstichele H, Vanmechelen E, Blennow K (1999) Cerebrospinal fluid beta-amyloid(1-42) in Alzheimer disease: Differences between early- and late-onset Alzheimer disease and stability during the course of disease. Arch Neurol 56, 673-680.

[6] Andreasen N, Blennow K (2005) CSF biomarkers for mild cognitive impairment and early Alzheimer's disease. Clin Neurol Neurosurg 107, 165-173.

[7] Lorenzi M, Donohue M, Paternicò D, Scarpazza C, Ostrowitzki S, Blin O, Irving E, Frisoni GB, Alzheimer's Disease Neuroimaging Initiative (2010) Enrichment through biomarkers in clinical trials of Alzheimer's drugs in patients with mild cognitive impairment. Neurobiol Aging 31, 1443-1451.

[8] Teunissen CE, Verwey NA, Kester MI, van Uffelen K, Blankenstein MA (2010) Standardization of assay procedures for analysis of the CSF biomarkers amyloid beta(1-42), tau, and phosphorylated tau in Alzheimer's disease: Report of an international workshop. Int J Alzheimers Dis 2010, pii: 635053.

[9] Mattsson N, Andreasson U, Persson S, Arai H, Batish SD, Bernardini S, Bocchio-Chiavetto L, Blankenstein MA, Carrillo MC, Chalbot S, Coart E, Chiasserini D, Cutler N, Dahlfors G, Duller S, Fagan AM, Forlenza O, Frisoni GB, Galasko D, Galimberti D, Hampel H, Handberg A, Heneka MT, Herskovits AZ, Herukka SK, Holtzman DM, Humpel C, Hyman BT, Iqbal K, Jucker M, Kaeser SA, Kaiser E, Kapaki E, Kidd D, Klivenyi P, Knudsen CS, Kummer MP, Lui J, Lladó A, Lewczuk P, Li QX, Martins R, Masters C, McAuliffe J, Mercken M, Moghekar A, Molinuevo JL, Montine TJ, Nowatzke W, rsquo O, Brien R, Otto M, Paraskevas GP, Parnetti L, Petersen RC, Prvulovic D, de Reus HP, Rissman RA, Scarpini E, Stefani A, Soininen H, Schröder J, Shaw LM, Skinningsrud A, Skrogstad B, Spreer A, Talib L, Teunissen C, Trojanowski JQ, Tumani H, Umek RM, Van Broeck B, Vanderstichele H, Vecsei L, Verbeek MM, Windisch M, Zhang J, Zetterberg H, Blennow K (2011) The Alzheimer's association external quality control program for cerebrospinal fluid biomarkers. Alzheimers Dement 7, 386-395.

[10] Bjerke M, Portelius E, Minthon L, Wallin A, Anckarsäter H, Anckarsäter R, Andreasen N, Zetterberg H, Andreasson U, Blennow K (2010) Confounding factors influencing amyloid beta concentration in cerebrospinal fluid. Int J Alzheimers Dis 2010, pii: 986310 .
[11] Lewczuk P, Beck G, Esselmann H, Bruckmoser R, Zimmermann R, Fiszer M, Bibl M, Maler JM, Kornhuber J, Wiltfang J (2006) Effect of sample collection tubes on cerebrospinal fluid concentrations of tau proteins and amyloid beta peptides. Clin Chem 52, 332-334

[12] Andreasen N, Minthon L, Davidsson P, Vanmechelen E, Vanderstichele H, Winblad B, Blennow K (2001) Evaluation of CSF-tau and csf-abeta42 as diagnostic markers for Alzheimer disease in clinical practice. Arch Neurol 58, 373-379.

[13] Slemmon JR, Meredith J, Guss V, Andreasson U, Andreasen N, Zetterberg H, Blennow K (2011) Measurement of Abeta142 in cerebrospinal fluid is influenced by matrix effects. J Neurochem 120, 325-333.

[14] Pica-Mendez AM, Tanen M, Dallob A, Tanaka W, Laterza OF (2010) Nonspecific binding of Abeta42 to polypropylene tubes and the effect of tween-20. Clin Chim Acta 411, 33.

[15] Perret-Liaudet A, Pelpel M, Tholance Y, Dumont B, Vanderstichele H, Zorzi W, Elmoualij B, Schraen S, Moreaud O, Gabelle A, Thouvenot E, Thomas-Anterion C, Touchon J, Krolak-Salmon P, Kovacs GG, Coudreuse A, Quadrio I, Lehmann S (2012) Cerebrospinal fluid collection tubes: A critical issue for Alzheimer disease diagnosis. Clin Chem $\mathbf{5 8}$, 787-789.

[16] Sweileh BA, Al-Hiari YM, Kailani MH, Mohammad HA (2010) Synthesis and characterization of polycarbonates by melt phase interchange reactions of alkylene and arylene diacetates with alkylene and arylene diphenyl dicarbonates. Molecules 15, 3661-3682.

[17] Nakanishi K, Sakiyama T, Imamura K (2001) On the adsorption of proteins on solid surfaces, a common but very complicated phenomenon. J Biosci Bioeng 91, 233 244.

[18] Gabelle A, Roche S, Gény C, Bennys K, Labauge P, Tholance Y, Quadrio I, Tiers L, Gor B, Boulanghien J, Chaulet C, Vighetto A, Croisile B, Krolak-Salmon P, Perret-Liaudet A, Touchon J, Lehmann S (2011) Decreased sA $\beta P P \beta, A \beta 38$ and A $\beta 40$ cerebrospinal fluid levels in frontotemporal dementia. J Alzheimers Dis 26, 553-563.

[19] Duncan M, Lee J, Warchol M (1995) Influence of surfactants upon protein/peptide adsorption to glass and polypropylene. Int J Pharm 120, 179-188.

[20] Poncin-Epaillard F, Mille C, Debarnot D, Zorzi W, Moualij BE, Coudreuse A, Legeay G, Quadrio I, Perret-Liaudet A (2011) Study of the adhesion of neurodegenerative proteins on plasma-modified and coated polypropylene surfaces. J Biomater Sci Polym Ed 2011 Sep 28. [Epub ahead of print].

[21] Zanini S, Riccardi C, Grimoldi E, Colombo C, Villa AM, Natalello A, Gatti-Lafranconi P, Lotti M, Doglia SM (2010) Plasma-induced graft-polymerization of polyethylene glycol acrylate on polypropylene films: Chemical characterization and evaluation of the protein adsorption. J Colloid Interface Sci 341, 53-58. 